\title{
Cytokinin Induction of Root Nodule Primordia in Lotus japonicus Is Regulated by a Mechanism Operating in the Root Cortex
}

\author{
Anne Birgitte Heckmann, Niels Sandal, Anita Søndergaard Bek, Lene Heegaard Madsen, \\ Anna Jurkiewicz, Mette Wibroe Nielsen, Leila Tirichine, and Jens Stougaard \\ Centre for Carbohydrate Recognition and Signalling, Department of Molecular biology, Aarhus University, Gustav Wieds vej 10, \\ DK-8000 Aarhus C, Denmark
}

Submitted 31 May 2011. Accepted 11 July 2011.

Cytokinin plays a central role in the formation of nitrogenfixing root nodules following inoculation with rhizobia. We show that exogenous cytokinin induces formation of discrete and easily visible nodule primordia in Lotus japonicus roots. The expression of nodulin genes was up-regulated upon cytokinin treatment, suggesting that the genuine nodulation program was indeed activated. This offers a simple approach for dissecting the underlying mechanism. Cytokinin-induced nodule primordia formation was unperturbed in several loss-of-function mutants impaired in epidermal responses to either rhizobial infection, Nod factor application, or both. However, absence of primordia in nsp1, nsp2, and nin mutants showed the requirement for these transcriptional regulators in the cytokinin-mediated activation of the root cortex. Distinguishing the epidermal and cortical responses further, we found that external cytokinin application induced expression of the Nin::GUS reporter gene within the root cortex but not in the root epidermis. Using L. japonicus lhk1-1 and harl mutants, we demonstrate that discrete activation of root cortical cells by cytokinin depends on the LHK1 cytokinin receptor and is subjected to HAR1-mediated autoregulation.

The symbiotic interaction between soil bacteria collectively called rhizobia and legume host plants leads to development of a new organ, the nitrogen-fixing root nodule. Bacterial infection of the legume root is tightly controlled at the epidermis and is also coordinated with the development of subtending nodule primodia in the root cortex.

In many legumes, infection is initiated when bacteria are entrapped by a curled root hair. Local cell-wall hydrolysis and invagination of the plasma membrane leads to formation of infection threads. These extend to the base of the root-hair cells and subsequently migrate into the root cortex, in which they ramify and release bacteria inside a subset of cells in the nodule primodia. In wild-type plants, each nodule primordium

Current address for Leila Tirichine: Génomique, Environnementale et Evolutive Section 3 CNRS UMR8197, Institut de Biologie de l'Ecole Normale Supérieure (IBENS), 46 rue d'Ulm, 75230 Paris CEDEX 05, France.

Corresponding author: Jens Stougaard; Telephone: +0045 8942 5011; Fax: +0045 8612 3178; E-mail: stougaard@ mb.au.dk

* The $\boldsymbol{e}$-Xtra logo stands for "electronic extra" and indicates that three supplementary figures and one supplementary table are published online. is targeted by an infection thread, but the final number of nitrogen-fixing nodules is controlled by the autoregulatory mechanism that limits the extent of root nodulation (Held et al. 2010; Oka-Kira and Kawaguchi 2006; Okamoto et al. 2009); Oldroyd and Downie 2008).

Analyses of loss-of-function mutants in Lotus japonicus have shown that perception of the Mesorhizobium loti lipochitin-oligosaccharide Nod factor by the NFR1 and NFR5 receptors is required to trigger the earliest physiological root responses that precede both infection and organogenesis, such as $\mathrm{Ca}^{2+}$ influx, membrane depolarization, and $\mathrm{Ca}^{2+}$ oscillations (spiking) (Madsen et al. 2003; Miwa et al. 2006; Radutoiu et al. 2003, 2007). Downstream from Nod factor perception, the signal transduction pathway encompasses a leucine-rich repeat receptor kinase (SYMRK), cation channels (CASTOR and POLLUX), nucleoporins (NUP85, NUP133, and NENA), a calcium calmodulin-dependent protein kinase (CCaMK), and a nuclear localized coiled-coil protein (CYCLOPS). Further downstream, putative transcriptional regulators of the NIN, GRAS (NSP1 and NSP2), and ERF families are required for upregulation of nodule-expressed genes and initiation of nodulation (Groth et al. 2010; Madsen et al. 2010). Taking advantage of the available L. japonicus symbiotic mutants, a detailed genetic dissection was performed and provided the basis for assigning the function of 16 key symbiotic genes to the infection or organogenic pathways or both (Madsen et al. 2010). In the organogenic pathway, Lhkl is required for activation of cell divisions and loss-of-function mutations, such as $l h k l-1$, impair the formation of nodule primordia (Murray et al. 2007; Tirichine et al. 2007). A gain-of-function mutation in the snf2 allele of the $L h k 1$ receptor gene leads to spontaneous development of empty nodules in the absence of either rhizobia, Nod factor signaling, or both (Tirichine et al. 2007). Results from L. japonicus (Murray et al. 2007; Tirichine et al. 2007) and parallel studies in Medicago truncatula (Gonzalez-Rizzo et al. 2006) suggest, therefore, that cytokinin signaling is necessary and also sufficient for organogenesis of the nodule structure.

Cytokinin has been proposed as a secondary signal that is synthesized in epidermal cells perceiving the Nod factor and is then translocated to underlying cortex cells, in which it triggers the initiation of nodule primordia ahead of the upcoming infection thread (Frugier et al. 2008; Murray et al. 2007; Oldroyd 2007; Tirichine et al. 2007). However, whether the initial cellular response to Nod factor signaling involves de novo cytokinin synthesis, release of conjugated (inactive) cytokinin, or cytokinin translocation, singly or in combination, remains unclear. 
Here, we report a simple experimental approach for investigating the effect of exogenous cytokinin in L. japonicus roots. We show that application of cytokinin to L. japonicus roots is sufficient for the formation of nodule primordia and that this process is blocked by nitrate and ethylene, as observed for rhizobia-induced nodules. Our results suggest that cytokinin activation of the cell cycle leading to cortical-cell division is limited by an as-yet-unidentified mechanism. It is presumed that this mechanism prevents widespread cell proliferation while promoting the formation of distinct cell division foci.

\section{RESULTS}

\section{6-Benzylaminopurine (BAP) and kinetin} induce root nodule-like structures in wild-type plants.

The mechanism or mechanisms connecting epidermal Nod factor signaling with activation of the cell cycle in subtending cortical cells forming the nodule primordia ahead of the rhizobial infection process is still unknown. Previous studies have used either spot-application or short exposure of roots and relatively high cytokinin concentrations (typically $10^{-4}$ to $10^{-6}$ M BAP) in attempts to mimic a local effect of cytokinin on root cortical cells (Bauer et al. 1996; Fang and Hirsch 1998; Hirsch et al. 1997; Mathesius et al. 2000). Contrasting these studies, we have used continuous exposure of whole roots to exogenous cytokinin at physiological levels $\left(10^{-8} \mathrm{M}\right)$. The question is how cytokinin-induced proliferation of cortical cells, assumed to be in the same state of specification, is regulated during formation of nodule foci.
Application of exogenous cytokinin has an inhibitory effect on root growth in L. japonicus ecotype Gifu. Elongation of roots is sensitive to rising levels of BAP, and high concentrations inhibit root elongation. In order to assess the role of the L. japonicus LHK1 cytokinin receptor in perception of exogenously applied cytokinin, the sensitivity of wild type, the $s n f 2$ gain-offunction and $l h k 1-1$ loss-of-function mutants, were assayed on plate-grown plants. Seeds were germinated until the radicle emerged and were then moved to agar plates containing cytokinin (BAP) in the $10^{-8}$ to $10^{-6} \mathrm{M}$ range and were scored after 5 to 6 weeks. Wild-type plants showed extreme stunted roots when grown in the presence of $10^{-6} \mathrm{M}$ BAP. Root elongation was also strongly inhibited at $10^{-7} \mathrm{M} \mathrm{BAP}$, while this concentration of cytokinin was less inhibitory for root elongation in the lhkl-1 mutants (Fig. 1A). At $10^{-8} \mathrm{M}$ BAP, root elongation of the snf2 mutant roots was already strongly inhibited.

In order to asses the influence of $10^{-8} \mathrm{M}$ BAP on the general root architecture in more detail, we quantified primary and lateral root length and the number of lateral roots. There was a significant reduction in the primary root length in wild-type plants grown on $10^{-8} \mathrm{M}$ BAP compared with plants grown under normal conditions (Fig. 1B). A significant reduction in primary root length was also observed for $l h k l-1$ after treatment with BAP. However, the length of lateral roots in wildtype plants was not significantly influenced by cytokinin and the number of lateral roots per plant was only significantly increased in the cytokinin-treated plants at the 14-day timepoint (Supplementary Table S1). An increased lateral root density was observed in cytokinin-treated wild-type plants compared
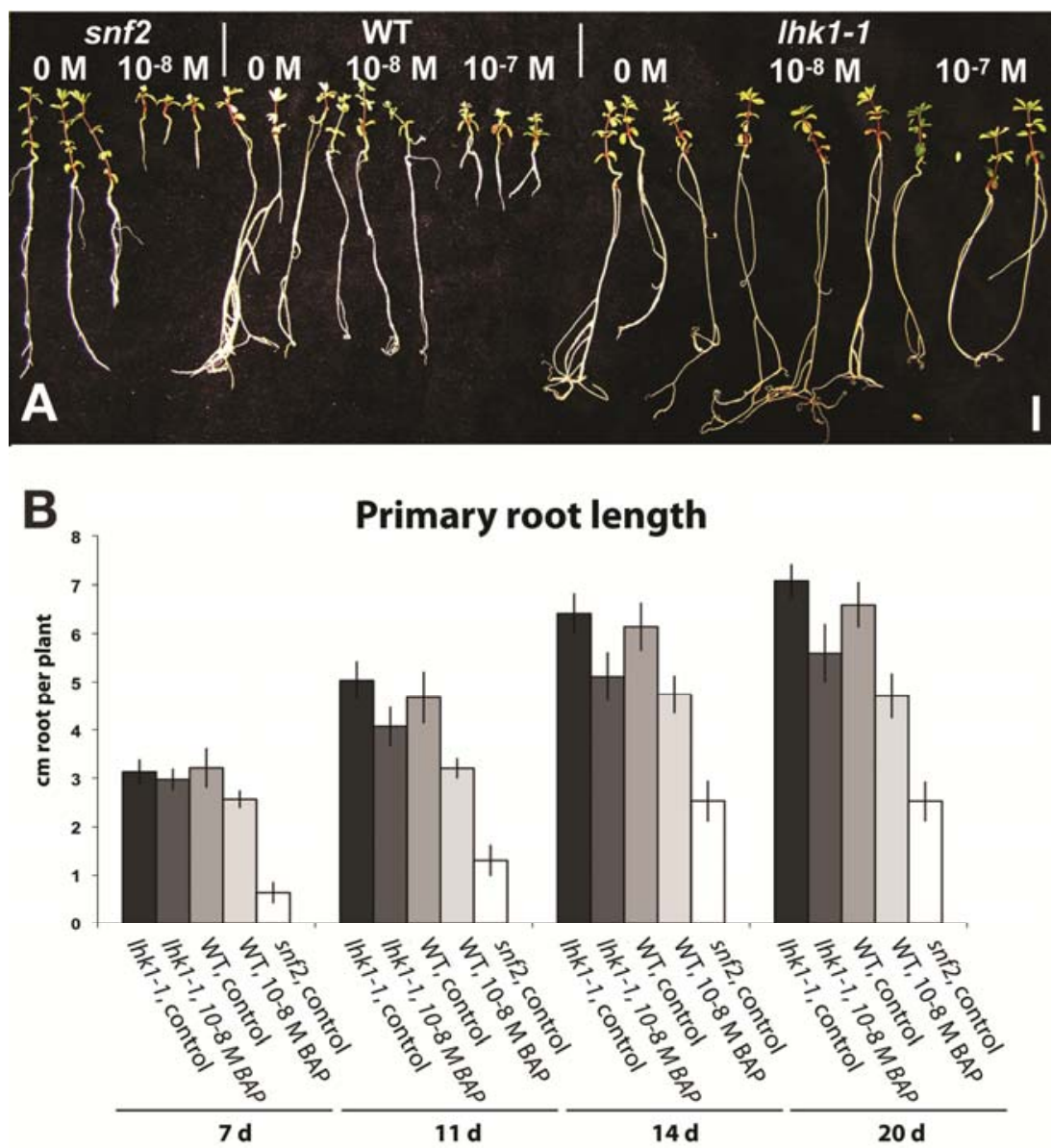

Fig. 1. The effect of cytokinin on root elongation of different Lotus japonicus plant lines. A, Wild-type, snf2, and lhk1-1 seedlings of $L$. japonicus ecotype Gifu were grown for 42 days on agar plates containing $10^{-8} \mathrm{M}$ 6-benzylaminopurine (BAP), $10^{-7} \mathrm{M}$ BAP, or no BAP as control. Scale bar $=1 \mathrm{~cm}$. B, The primary root length of $l h k 1-1$, wild type, and snf 2 was investigated following growth on B\&D media without (control) and with $10^{-8} \mathrm{M}$ BAP. $95 \%$ confidence intervals are indicated. 
with untreated plants at the 14- and 20-day timepoints, and this was reflected in higher root weight. In the lhkl-1 mutants, both a significant lower lateral root density and fewer lateral roots were observed at the 14- and 20-day timepoints, and the lateral root length at 20 days was also significantly lower in cytokinin treated plants (Supplementary Fig. S1).

When inspecting wild-type plants grown for 4 weeks on $10^{-8}$ M BAP, an additional local effect of cytokinin was observed. Discrete root nodule-like structures had emerged (Fig. 2A). The morphology of BAP-induced nodule-like structures ranged from small bumps (Fig. 2A) to relatively large empty nodules (Fig. 2B). Small bumps were occasionally seen like pearls on a string, as shown in Figure 2A. In contrast, no such nodule structures were observed in the $l h k l-1$ mutant.
To compare the effect of different cytokinins, plants were grown on kinetin or trans-zeatin at concentrations of $10^{-7}$ and $10^{-8} \mathrm{M}$. These concentrations did not result in nodule formation or any inhibition of root growth. Discrete root nodule-like structures were observed, however, when plants were exposed to a higher concentration of kinetin $\left(10^{-6} \mathrm{M}\right)$, demonstrating that the observed effect was not specific for BAP.

\section{Anatomy of the cytokinin root nodule primordia.}

Cytokinin-induced nodule primordia emerged later than rhizobial-induced primordia. Whereas bacteria-induced nodule primordia can be observed within 9 days after inoculation, comparable cytokinin-induced primordia were visible to the naked eye 18 days after cytokinin treatment. To further investi-
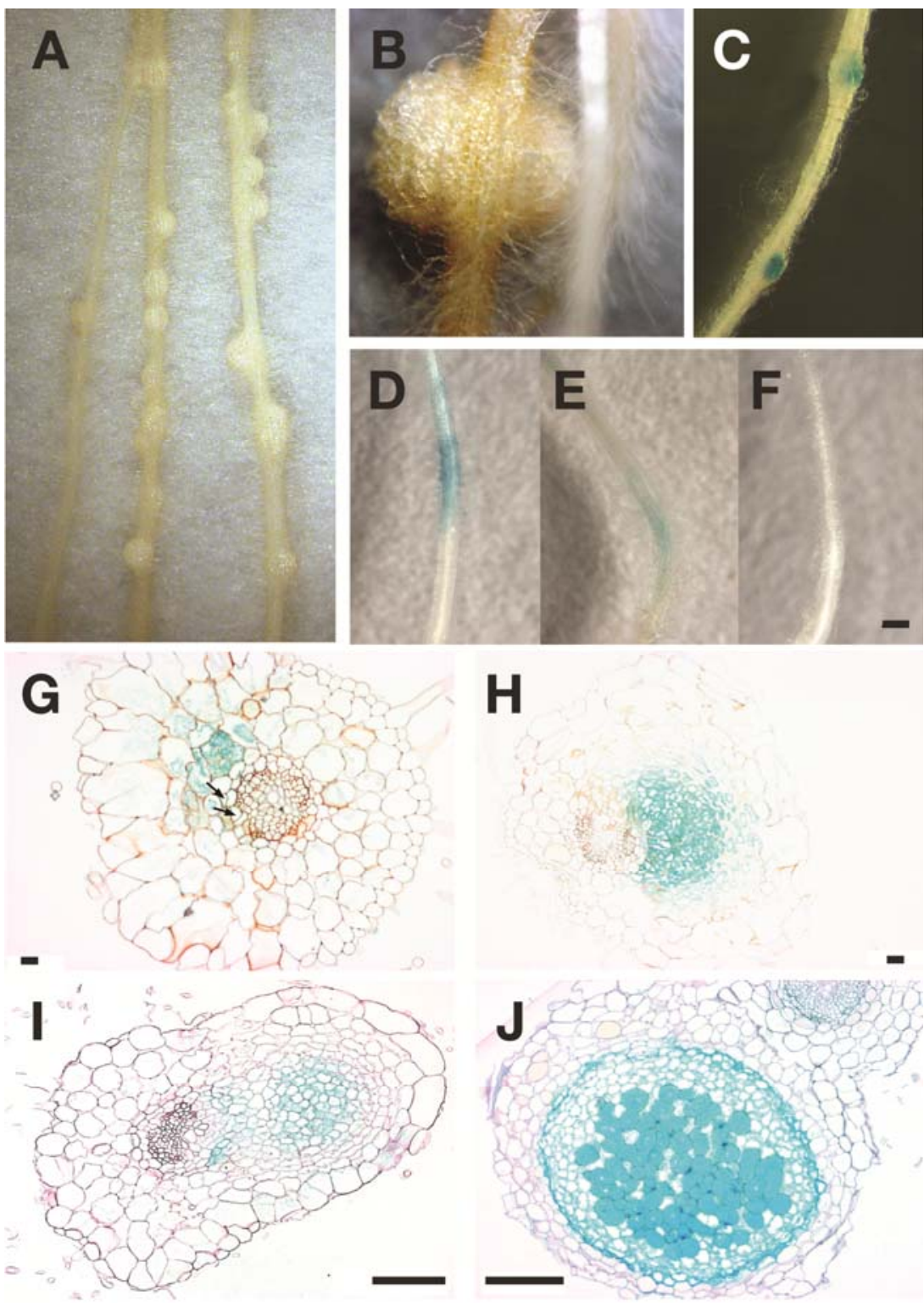

Fig. 2. Nodule primordia induced by exogenous cytokinin. A, The formation of nodule primordia can be observed on L. japonicus ecotype Gifu seedlings when grown on agar plates containing $10^{-8} \mathrm{M}$ benzylaminopurine (BAP). B, Relatively large and round nodules can also be found following $10^{-8} \mathrm{M}$ BAP treatment $\mathbf{C}$, Nin::GUS expression is observed in the cytokinin-induced root-nodule primordia following growth with $10^{-8} \mathrm{M}$ BAP for 21 days. The blue staining shows expression of the Nin::GUS promoter fusion. D, E, and F, Comparison of Nod factor and cytokinin induction of Nin::Gus in epidermal cells. D, Expression observed following inoculation with Mesorhizobium loti, and $\mathbf{E}$, treatment with $10^{-7}$ Nod factor or F) $10^{-7} \mathbf{M ~ B A P . ~ S c a l e ~ b a r ~}=500 \mu \mathrm{m} . \mathbf{G}, \mathbf{H}$, $\mathbf{I}$, and $\mathbf{J}$, Thin section of cytokinin-induced root nodule primordium (10 ${ }^{-8} \mathrm{M}$ BAP) and M. loti in Nin::GUS plants. G) Arrows indicate division of cortical cells in a cytokinin-induced primordium and $\beta$-glucuronidase (GUS) activity can be observed in and around the dividing cells. Scale bar $=10 \mu \mathrm{m}$. $\mathbf{H}, \mathrm{A}$ small cytokinin-induced nodule shows GUS staining in the dividing cortex cells. Scale bar $=20 \mu \mathrm{m}$. I, Thin section of a Nin::GUS cytokinin-induced $\left(10^{-8} \mathrm{M}\right.$ BAP) nodule showing normal nodule structure, however, without the presence of bacteria inside. GUS activity can be observed inside the nodule cells. Scale bar $=100 \mu \mathrm{m}$. J, Thin section of a Nin::GUS root nodule induced by $M$. loti showing the presence of infected cells inside the nodule. Scale bar $=50 \mu \mathrm{m}$. 
gate the nature of the nodule-like structures, expression of the Nin::GUS promoter fusion was determined. Nin encodes a putative transcriptional regulator required for infection thread formation and inception of nodule primordia. Nin is first expressed in epidermal cells a few hours after inoculation with $M$. loti and expression continues in cells forming the nodule primordia, thus serving as a marker for both initiation and development (Schauser et al. 1999).

Wild-type plants homozygous for the Nin::GUS transgene were grown on $10^{-8} \mathrm{M}$ BAP and GUS ( $\beta$-glucuronidase) activity was visualized after three weeks of growth. As shown in Figure 2C, expression of the Nin gene promoter was detected only in the cytokinin-induced primordia. Sectioning of the cytokinin-induced primordia shows that the localization of GUS activity is similar to the cellular location of Nin::GUS expression in M. loti-induced root nodule primordia (Fig. $2 \mathrm{H}$, I, and J).

In order to distinguish the epidermal and cortical responses observed during nodulation, the Nin::GUS plants were inoculated with $M$. loti or were treated with cytokinin $\left(10^{-6}, 10^{-7}\right.$, $10^{-8}$, or $10^{-9} \mathrm{M}$ BAP) or Nod factor $\left(10^{-7} \mathrm{M}\right)$. After $48 \mathrm{~h}$, expression in epidermal cells were observed in 40 of 45 plants inoculated with $M$. loti and in 14 of 39 plants treated with Nod factor (Fig. 2D and E). Cytokinin did not induce detectable levels of GUS expression in epidermal cells of 48 plants (Fig. 2F). Inspection of thin sections also localized dividing root cells presumably founding primordia from the root cortex of cytokinin-treated roots (Fig. 2G).
Expression of early nodulin genes in cytokinin-induced primordia.

In order to compare nodulin gene expression in Nod factorinduced and cytokinin-induced root tissue, we measured transcript levels of a transcription factor, Hap2, similar to the Arabidopsis NF-YA gene, Nin, and a type-A cytokininresponse regulator (Lrr5). The Hap2 gene is expressed in root tissue of L. japonicus very early following inoculation with rhizobia (Høgslund et al. 2009), and in Medicago truncatula, a homologous gene was shown to be a key transcriptional regulator of symbiotic nodule development (Combier et al. 2006). Additionally, the transcript level of the Lrr5 gene has previously been shown to be up-regulated in L. japonicus following cytokinin treatment and in the snf2 gain-of-function mutant (Tirichine et al. 2007).

We determined transcript levels in root tissue following treatment with either $10^{-7} \mathrm{M}$ Nod factor or $10^{-8} \mathrm{M}$ BAP. Both the Hap2 and Nin gene expression were up-regulated in a similar manner following a 3-h treatment with either cytokinin or Nod factor (Fig 3A and B). However, the transcript levels for both genes peaked after 3 to $6 \mathrm{~h}$ following Nod factor treatment, while the expression either reached a steady state (Nin) or showed a continuous upregulation (Hap2) after $12 \mathrm{~h}$ of treatment with cytokinin (Fig. 3A and B). The two GRAS transcription factor genes, $N s p l$ and $N s p 2$, also showed differences in expression following cytokinin treatment, as compared with Nod factor (Fig. 3C and D) (Maekawa et al. 2009;
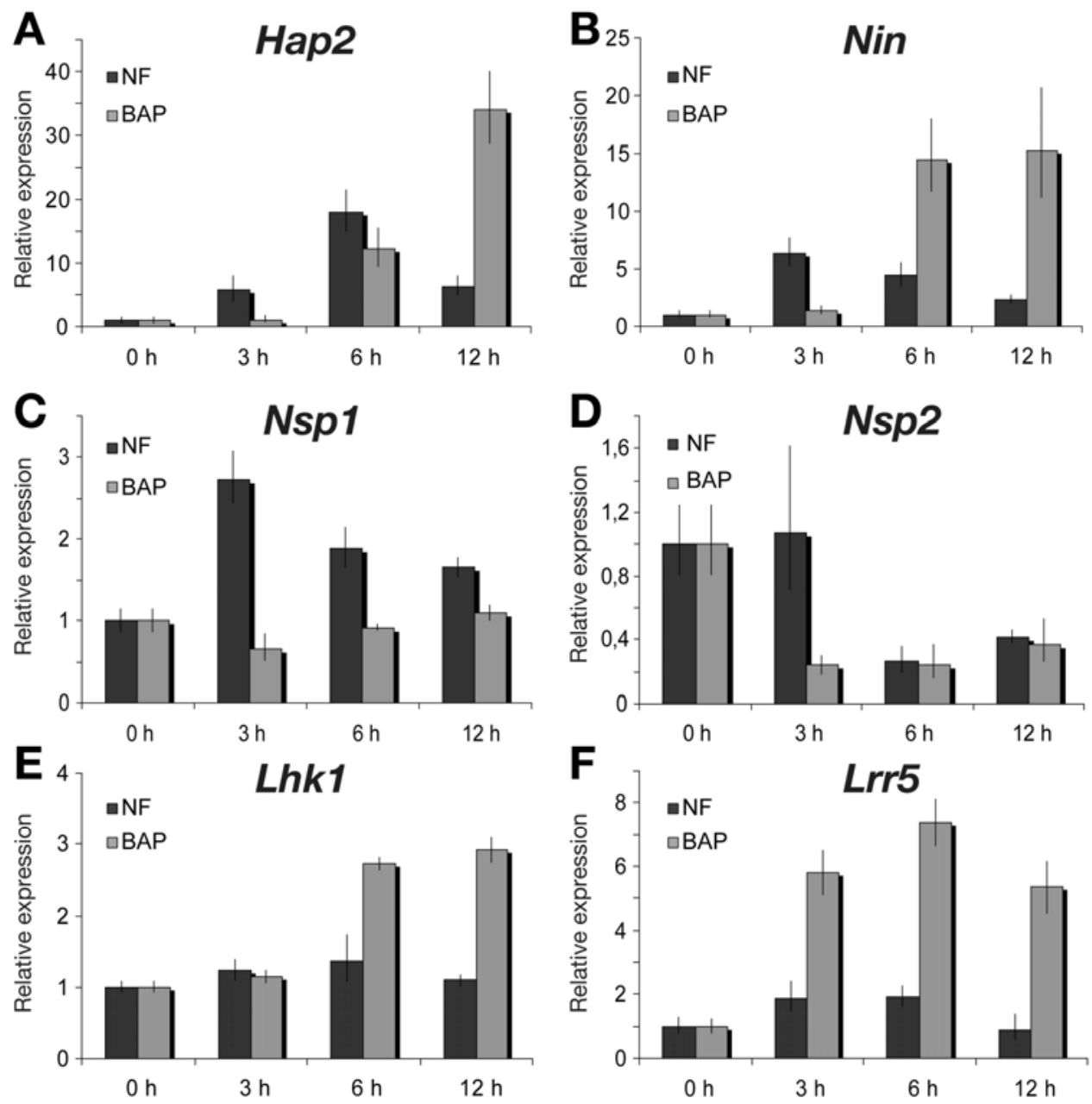

Fig. 3. The relative expression of root nodule primordial marker genes after application of cytokinin or Nod factor. Time course of Hap2, Nin, Nsp1, Nsp2, Lhk1, and Lrr 5 expression in root tissue after treatment with $10^{-7} \mathrm{M}$ Nod factor or $10^{-8} \mathrm{M}$ benzylaminopurine. As internal controls ATP synthase, PP2a, and ubiquitin-conjugating enzyme (UBC) were used, and 95\% confidence intervals are indicated. 
Plet et al. 2011). An increase in Nspl transcript was already seen $3 \mathrm{~h}$ after Nod factor application, whereas no significant changes in expression levels were seen for cytokinin treatment at any timepoint. $N s p 2$, on the other hand, showed a clear decrease in transcription levels following cytokinin and Nod factor treatments as previously observed (Gonzalez-Rizzo et al. 2006; Maekawa et al. 2009). Addition of cytokinin also regulates the expression of the $L h k l$ receptor gene itself, resulting in a rapid increase in $L h k l$ gene transcript (Tirichine et al. 2007). This increase in Lhkl transcript was, however, not detected upon Nod factor treatment (Fig 3E). Finally, Lrr5 also showed rapid changes in transcript levels. Upon BAP treatment, the Lrr5 gene showed a more than sixfold increase in transcript compared with untreated root material, whereas only a small but significant upregulation could be observed upon Nod factor treatment (Fig 3F). Although the presence of cytokinin was continuous, the transcript level was lower after $12 \mathrm{~h}$. These data confirm the activation of the early nodulation pathway upon cytokinin treatment, even though the continued regulation of the investigated genes is different from that seen after Nod factor treatment.

The expression of late nodulation genes was investigated in roots carrying cytokinin-induced nodule primordia following treatment with $10^{-8} \mathrm{M}$ BAP for 21,28 , and 35 days. Tissue from whole root 7 and 14 days postinoculation (dpi) with rhizobia was also analyzed for comparison of transcript levels during formation of rhizobia-induced nodules. The data showed no difference in transcript levels of $L h k l$ for the two different treatments. No change in transcript levels of Nin was observed in the cytokinin-treated plants, whereas the levels in rhizobiainoculated plants were several-fold higher at both 7 and 14 dpi (Supplementary Fig. S2). Sst1 is a sulphate transporter found to be crucial for symbiotic nitrogen fixation in L. japonicus root nodules. The gene is expressed late in a nodule-specific manner and encodes a putative sulphate transporter (Krusell et al. 2005). Sst1 was not up-regulated upon cytokinin treatment.

\section{Nitrate, ethylene, and abscissic acid (ABA) responses.}

In order to determine whether the physiological response of cytokinin-induced primordia corresponds to rhizobial-induced primordia, the effect of nitrate and ethylene, known to inhibit primordia formation, was investigated. Rhizobial nodulation of L. japonicus is nitrogen-sensitive, and in the presence of high concentrations of nitrate, nodulation is suppressed (Wopereis et al. 2000). This is also seen in the spontaneously nodulating mutant snf2 (Tirichine et al. 2006b). Under these conditions, nodule organogenesis is arrested, resulting in a reduced number of nodules and development of prematurely arrested nod-
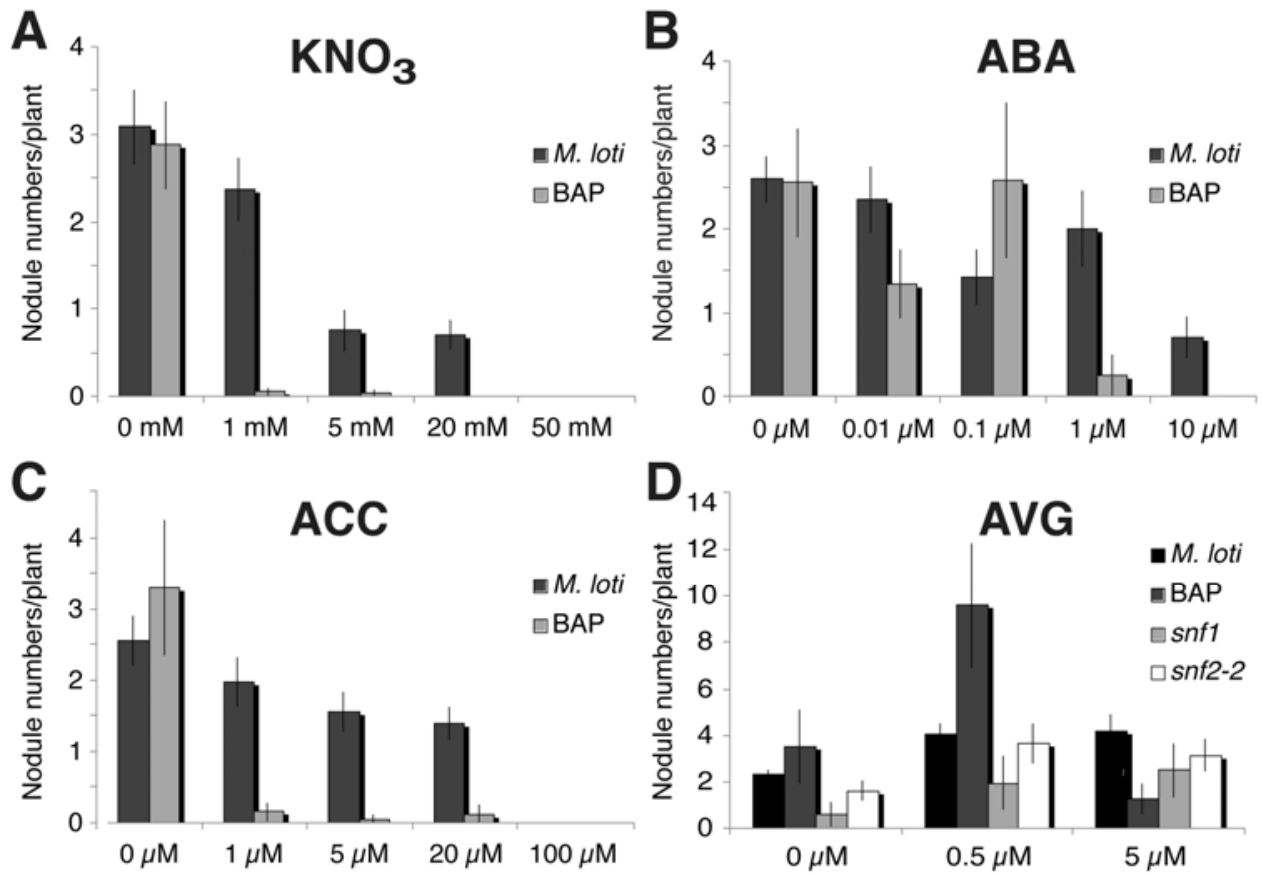

Fig. 4. The effect of nitrate, abscissic acid (ABA), and ethylene on cytokinin-induced formation of nodule primordia (10 ${ }^{-8} \mathrm{M}$ benzylaminopurine for 42 days). A, Effects of increasing levels of nitrate were investigated on Mesorhizobium loti- and cytokinin-induced nodulation. B, Effects of increasing levels of ABA were investigated on $M$. loti- and cytokinin-induced nodulation. C, Effects of increasing levels of the ethylene precursor 1-aminocyclopropane-1carboxylic acid (ACC) were investigated on $M$. loti- and cytokinin-induced nodulation. D, Effects of increasing levels of ethylene synthesis inhibitor aminoethoxyvinylglycine (AVG) were investigated on $M$. loti- and cytokinin-induced nodulation. Confidence intervals at $95 \%$ are indicated.

Table 1. Nodulation in transgenic hairy roots expressing either the wild type $L h k 1$ or the snf2 gain-of-function cytokinin receptor

\begin{tabular}{|c|c|c|c|c|c|c|}
\hline \multirow[b]{2}{*}{ Genotype/species } & \multirow[b]{2}{*}{ Construct } & \multicolumn{4}{|c|}{ Number of } & \multirow[b]{2}{*}{$\%$ spontaneous nodulation } \\
\hline & & Plants & Spontaneous nodules & Nodules per plant & Nodulated plants & \\
\hline Gifu & Lhk1 & 37 & 0 & 0 & 0 & 0 \\
\hline Gifu & snf2 & 99 & 187 & 1.9 & 31 & 31 \\
\hline MG-20 & Lhk1 & 60 & 0 & 0 & 0 & 0 \\
\hline MG-20 & $\operatorname{snf} 2$ & 53 & 13 & 0.25 & 8 & 15 \\
\hline Lotus filicaulis & Lhk1 & 55 & 0 & 0 & 0 & 0 \\
\hline L. filicaulis & $\operatorname{snf} 2$ & 77 & 0 & 0 & 0 & 0 \\
\hline L. burttii & Lhk1 & 6 & 0 & 0 & 0 & 0 \\
\hline L. burttii & $\operatorname{snf} 2$ & 21 & 281 & 13.4 & 21 & 100 \\
\hline
\end{tabular}


ule structures rather than functional nodules. To examine this aspect of nitrogen regulation, cytokinin induction of primordia was scored on plates containing increasing concentrations of potassium nitrate. The cytokinin-induced nodule number decreases significantly at $1 \mathrm{mM}$ of $\mathrm{KNO}_{3}$, and at $20 \mathrm{mM}$, formation of nodules was not observed (Fig. 4A). For comparison, results from nitrate suppression of $M$. loti-induced nodules are included in Figure 4.

Ethylene regulates rhizobia-induced nodulation negatively (Goodlass and Smith 1979; Peters and Cristestes 1989). Addition of exogenous ethylene to nodulating pea, alfalfa, and $L$. japonicus plants reduces the frequency of nodule primordium formation (Heidstra et al. 1997; Nukui et al. 2000; Oldroyd et al. 2001), and treatment of certain legumes with AVG (aminoethoxyvinylglycine), an inhibitor of ACC (1-aminocyclopropane carboxylic acid) synthase, increases nodule numbers (Peters and Cristestes 1989; Zaat et al. 1989). To determine whether ethylene has a regulatory effect on cytokinin-induced primordia formation, different concentrations of ACC, a precursor of ethylene, were added in plate tests. The number of nodule primordia was scored after 4 to 5 weeks, and cytokinin-induced nodule numbers, as well as $M$. loti-induced nodules, decline with increasing concentrations of the ethylene precursor ACC (Fig. 4C). To compare nodule numbers in the presence and absence of endogenous ethylene biosynthesis, seedlings were grown in the presence of AVG. Interestingly, the number of nodules observed on cytokinin-treated plants was significantly higher than on the $M$. loti-treated plants when grown on $0.5 \mu \mathrm{M}$ AVG (Fig. 4D). This difference, however, was changed at $5 \mu \mathrm{M} A V G$, when the nodule numbers were significantly higher in $M$. lotitreated plants as compared with the cytokinin treatment. When either of the two spontaneous nodulators, snfl or snf2, were grown with the addition of AVG, the nodule numbers were also slightly higher than observed for the control plants. Higher amounts of AVG are known to have an inhibitory effect on root elongation, which can also be observed in this study (Supplementary Fig. S3). This might explain the observed reduction in nodule numbers when using $5 \mu \mathrm{M}$ AVG. However, wild-type, snfl, and snf 2 mutants did not show this reduction, indicating that AVG inhibition of auxin biosynthesis as recently observed in Arabidopsis may influence the AVG results (Soeno et al. 2010). Root growth was inhibited slightly by the AVG treatment and as expected by the ACC treatment as well.
ABA was recently also shown to inhibit nodule formation (Ding et al. 2008; Suzuki et al. 2004; Tominaga et al. 2009). ABA was found to inhibit formation of nodules, and the inhibiting effect was observed at lower concentrations for the cytokinin-induced nodule primordia (Fig. 4B). A reduction in nodule numbers was observed at $1 \mu \mathrm{M}$ ABA for cytokinintreated plants, whereas a concentration of $10 \mu \mathrm{M}$ ABA was required for a clear reduction in nodule numbers for $M$. lotiinoculated plants. The nodule-inhibiting effect observed for all investigated treatments showed similar trends for M. loti- and cytokinin-treated plants with the exception of AVG.

\section{Exogenous cytokinin acts downstream of Nod factor signal transduction.}

Previous analysis of the snf2 gain-of-function mutant showed that empty root-nodule primordia can be formed spontaneously in the absence of rhizobia or Nod factor signaling. Formation of spontaneous root nodules was, however, dependent on the Nin and Nsp2 genes, suggesting that the transcriptional regulators required for cortical cell activation were required for cytokinin-mediated cell activation (Tirichine et al. 2007). The notion that primordia induced by exogenous cytokinin are activated through the rhizobial pathway could, therefore, be tested in mutants impaired in genes mediating Nod factor signal transduction or genes responsible for downstream developmental events. Application of $10^{-8} \mathrm{M}$ BAP to $n f r l$, nfr5, symRK, nup133, nup85, castor, pollux, and ccamk lossof-function mutants results in nodule primordia. This observation indicates that cytokinin acts independently or downstream of the Nod factor signal transduction pathway. Absence of cytokinin-induced primordia in nin, nspl, nsp2, and lhkl-1 mutants shows that cytokinin acts downstream of Nod factor perception and, furthermore, shows that cytokinin-induced primordia are dependent on the genes required for cortical cell activation and division. To substantiate this interpretation, a set of mutants developing primordia or root nodules arrested during development were examined for cytokinin induction of primordia. The pirl and cyclops mutants affected in infectionthread formation and progression (Yano et al. 2008; Yokota et al. 2009) and the sym10, sym11, and sym43 mutants developing ineffective root nodules (Sandal et al. 2006; Suganuma et al. 2003) all responded to BAP and primordia appeared. Two hypernodulating mutants, astray and harl (Krusell et al. 2002;

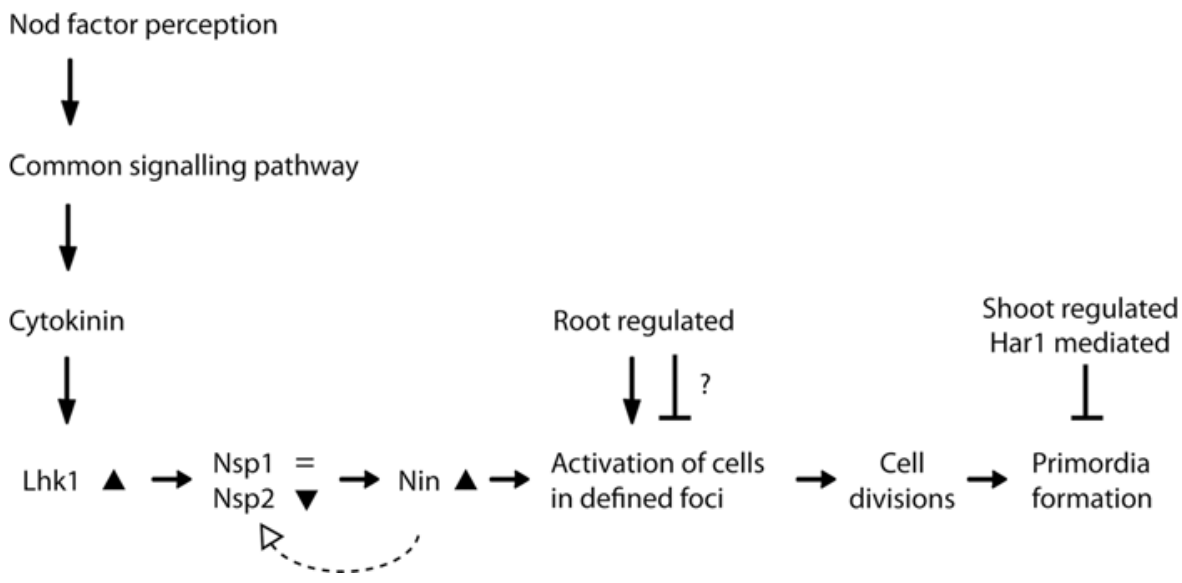

Fig. 5. Model of cytokinin perception and downstream responses in Lotus japonicus. Exogenously applied cytokinin is perceived by the root through the Lhk1 receptor, resulting in the formation of nodule primordia. Signaling progressing through the transcriptional regulators Nsp1, Nsp2, and Nin results in activation of cell divisions. The divisions are delimited in foci, suggesting that only some cells are responding. This indicates a control mechanism operating throughout the whole root system to prevent excessive cell proliferation. Additionally, the shoot-mediated autoregulation of nodule numbers dependent on the Harl gene, which controls the number of foci forming nodule primordia, even in the presence of cytokinin. The arrowheads and equal sign symbolizes gene expression patterns upon application of cytokinin. The dotted line indicates a possible complex feedback regulation mechanism, as it has been shown that Nin expression is not solely dependent on Nsp2 during cytokinin induction, at least in the early response after 6 h (Maekawa et al. 2009). However, microarray analysis of L. japonicus mutants demonstrated that the rhizobia-induced Nsp2 upregulation depends on an active Nin gene (Høgslund et al. 2009). 
Nishimura et al. 2002a and b; Wopereis et al. 2000), seemed to respond to cytokinin in a similar way as to bacteria, by producing more nodule primordia, $5.1(P>0.001)$ and $5.5(P>0.01)$ nodules per plant, respectively, compared with 2.8 nodules per plant on cytokinin-treated wild-type plants. This suggests that the cytokinin-mediated reactivation of the cell cycle leading to development of nodule primordia acts upstream of autoregulation.

\section{Biodiversity and the cytokinin response.}

Induction of cortical-cell divisions was previously observed in alfalfa following spot-application or short exposure using $10^{-5}$ to $10^{-6}$ M BAP (Bauer et al. 1996; Fang and Hirsch 1998; Hirsch et al. 1997). These cell divisions were initiated by cells in the inner cortex, forming foci of primordial cells. However, the size of the primordia formed and reproducibility varied between species and reports (Fang and Hirsch 1998; Hirsch et al. 1997; Mathesius et al. 2000). Different legumes seem, therefore, to vary in their response to exogenous application of cytokinin, and in order to examine this further, a selection of four Lotus ecotypes and species were tested. Only L. japonicus ecotype Gifu responded with development of visible nodule primordia following growth on $10^{-8} \mathrm{M}$ BAP, while the closely related ecotype L. japonicus MG-20 showed no cytokinin response detectable by stereomicroscopy of roots. L. filicaulis was similarly unresponsive, while L. burttii responded to cytokinin with an elongated root swelling near the root tip. Development of nodules was also tested at $10^{-8}$ to $10^{-5} \mathrm{M}$ BAP $(L$. japonicus Gifu, MG-20, and L. filicaulis) and $10^{-10}$ to $10^{-5}(\mathrm{~L}$. burttii), without any observable change in response. These observations suggested that cytokinin signaling is regulated not only by the cytokinin levels but also by components of the signal transduction and perception pathway. Addressing this possibility, the $s n f 2$ gain-of-function allele and the $L h k 1$ gene from the Gifu ecotype was expressed in transgenic roots of the other Lotus ecotypes and species. Both MG-20 and L. burttii transformed with snf2 developed spontaneous root nodules, reaffirming the role of cytokinin signaling in primordia formation (Table 1). The L. burttii transgenic root system was, with approximately 13 spontaneous root nodules per plant, even more responsive than the Gifu transgenic roots, which developed around two spontaneous nodules per plant. MG-20 was less responsive to the gain-of-function $\sin 2$ allele, while $L$. filicaulis transformed with snf2 was unresponsive (Table 1).

\section{DISCUSSION}

Here, we show that diffusion of exogenously applied cytokinin results in distinct and localized formation of root nodule primordia in the Lotus japonicus Gifu ecotype. In this study, relatively low amounts of cytokinin were required for the formation of nodules on L. japonicus as compared with previously described activation of cortical-cell divisions or Enod40 gene activation in other legume plant species following spot-application or short exposure, typically 4 days (Bauer et al. 1996; Fang and Hirsch 1998; Hirsch et al. 1997; Mathesius et al. 2000). The physiological concentration of cytokinin has been reported to be $13.75 \mathrm{pmol}$ per gram of fresh weight and 0.01 to $2 \mathrm{nM}$ in Arabidopsis and maize, respectively (Takei et al. 2001; Werner et al. 2001). Although measurements are not available from L. japonicus, it appears that the concentrations of cytokinin used to obtain nodules on L. japonicus Gifu is in the range of the normal physiological concentrations and lower than those previously used in spot-application or short exposure on species like pea and alfalfa (Allen et al. 1953; Fang and Hirsch 1998; Hirsch and Fang 1994; Hirsch et al. 1989, 1997).
The L. japonicus cytokinin-induced nodules described here appear to have the hallmarks of rhizobial-induced nodules. Inspection of sections of cytokinin-induced nodules in L. japonicus show cell divisions initiated in the cortex of the root (Fig. $2 \mathrm{G})$. In L. japonicus, the first cortical-cell divisions have been observed in the outer cortex (Szczyglowski et al. 1998) and in the third cortical cell layer (van Spronsen et al. 2001). The cytokinin-induced primordia appears to originate from the third cortical cell layer as the rhizobial-induced primordia reported by van Spronsen and associates (2001). This indicates a common ontogeny between the two types of nodules. Additionally, we did not observe a central vascular bundle in the cytokinininduced nodules, whereas the previously described structures obtained with auxin transport inhibitors were connected to the root with a central vascular bundle like lateral roots (Hirsch et al. 1989). At the level of gene expression, cytokinin leads to activation of the signaling pathway normally resulting in the formation of nodules. However, diffusion of cytokinin presumably results in prolonged activation of some of the genes, for example, Nin and Hap2, involved in the formation of the nodule primordia. Application of exogenous cytokinin did not result in upregulation of Nspl transcript levels, in contrast to what is seen with Nod-factor treatment. NSP1 is a DNA-binding protein, and it has been shown to bind directly to the promoter of Nin (Hirsch et al. 2009). Nsp2 showed a clear decrease in transcription levels following cytokinin and Nod factor treatments. This is somewhat opposite of previous studies showing that Nsp2 is required for rhizobia-induced Nin expression (Murakami et al. 2007) and required for the gain-of-function snfl $(C C a M K)$ (Tirichine et al. 2006a) and snf2 spontaneous nodulation (Tirichine et al. 2007) as well as for cytokinin-induced nodulation (this paper).

In alfalfa and clover, spot-application or short exposure of cytokinin has been shown to induce inner cortical-cell divisions (Fang and Hirsch 1998; Hirsch et al. 1997; Mathesius et al. 2000). Likewise, prolonged local exposure by expressing a cytokinin biosynthesis tzs gene in a Sinorhizobium meliloti mutant unable to synthesize Nod factor resulted in development of nodule-like structures on alfalfa (Cooper and Long 1994). However, the spot-application or short exposure techniques used provide very limited resolution of the interaction between cytokinin signaling and the regulatory mechanism operating at the whole-root level. Using an approach in which physiological cytokinin levels were applied to the whole root, we show that the systemic autoregulation normally restricting the number of nodule primordia formed on rhizobia-inoculated plants also regulates cell divisions following cytokinin treatment. Both hypernodulating mutants astray and harl seem to respond to cytokinin in a similar way as for bacteria by producing more cytokinin-induced nodules than wild type. This indicates that autoregulation operates downstream of cytokinin signaling, as also observed using snf2 harl double mutants (Tirichine et al. 2007). More importantly, our results with application of cytokinin suggest another layer of control that limits activation of the cell cycle into foci and, simultaneously, prevents excessive cell activation and cell proliferation. This control must be active in the entire root system, as cytokinin addition results in the formation of controlled local cell division and not prolific cell divisions along the length of the root. We suggest that regulation of root nodule numbers is a two-step process in which cytokinin induces a limited number of cell division foci and that the further development of these foci are subsequently controlled by the autoregulatory mechanism (Fig. 5). This concurs with observations in soybean that, like L. japonicus, develops determinate nodules. In soybean, inhibition of nodulation occurs after initiation of cortical-cell division clusters (Mathews et al. 1989). In contrast, autoinhibition acts earlier on plants like pea and Medicago sativa, forming 
indeterminate nodules, resulting in the nodule-inhibited root zones lacking cortical-cell divisions (Caetano-Anollés and Gresshoff 1991; Sagan and Gresshoff 1996).

Several lines of evidence show that cytokinin is involved in the early signaling pathway acting downstream of the CCaMK expected to be activated by Nod-factor signaling. The ability of the loss-of-function mutants of the Nod-factor signal transduction pathway to respond to cytokinin confirmed the earlier reported data with transformation of the snf2 gene into some of these mutants (Tirichine et al. 2007). Lack of nodules in the lhkl-l loss-of-function Lhkl mutant verifies that the cytokinin signal resulting in nodulation does signal through the LHK1 receptor. Except for $l h k 1-1$, only mutants in the transcription factors $n s p 1$, nsp2, and nin are impaired in nodule development following exposure to cytokinin. Altogether, this corroborates the position of the LHK1 receptor in the signal transduction pathway after CCaMK and positions the activity of the transcription regulators downstream of the cytokinin signal and in the cortical cells. A similar conclusion was reached in a double-mutant analysis (Madsen et al. 2010). During formation of nodules, activation and coordination of two separate processes are ongoing, the bacterial infection in the epidermis and cell divisions in the root cortex. The two processes must be interlinked; however, an unperturbed cytokinin induction in the pirl and cyclops mutants affected in infection-thread formation indicates that lack of normal infection-thread progression may not limit the cytokinin signaling and the ability of cortical cells to perceive the signal. Along the same line, our results showing cytokinin activation of Nin::GUS in the cortical cells but not in epidermal cells would suggest that, under normal rhizobial infection, cytokinin may not be synthesized in the epidermal cells and translocated to subepidermal layers. This, however, needs further proof using another cytokinin reporter and studies of the cytokinin biosynthesis pathway.

The effect of the addition of cytokinin to $l h k l-l$ loss-of-function and snf2 gain-of-function mutants suggests that the LHK1 receptor has a prominent function in perception of external cytokinin at the whole-root level that also influences root architecture. A cytokinin-induced inhibition of the main root was observed in both wild-type and $l h k l-1$ plants; however, wild-type plants were observed to be more sensitive to the cytokinin treatment than $l h k l-1$, while the gain-of-function $s n f 2$ mutants were hypersensitive to cytokinin. Cytokinin treatment also leads to reduced lateral root formation and lateral root density in the $l h k 1-1$ mutants. Surprisingly, at the 14 day timepoint, the lateral root density as well as lateral root numbers were significantly increased in wild-type plants treated with $10^{-8} \mathrm{M}$ BAP as compared with untreated wild type. This effect of cytokinin appears to differ from results obtained in Arabidopsis and rice (Laplaze et al. 2007; Debi et al. 2005). Here, cytokinin was shown to act directly on lateral root-founder cells to inhibit root initiation (Laplaze et al. 2007; Debi et al. 2005); however, in rice, lateral root elongation was stimulated (Debi et al. 2005). Growth of the main root in $l h k l-1$ and Mtcrel mutants was previously suggested to be insensitive to cytokinin (Murray et al. 2007; Plet et al. 2011), and the lateral root density or lateral root numbers were enhanced in the MtCrel RNA interference (RNAi) roots (Gonzalez-Rizzo et al. 2006) and transgenic L. japonicus roots carrying AtCkx3 or ZmCkxl (Lohar et al. 2004), respectively. Although similar questions are addressed in these experiments, the results cannot be directly compared. In contrast to our conditions, the lhkl-1 mutants were grown in the presence of BAP for 10 days in total darkness, in the presence of sucrose and on agar without filter paper (Murray et al. 2007). Furthermore, the MtCre1 RNAi, AtCkx3, and ZmCkxl results were obtained in hairy roots (Gonzalez-Rizzo et al. 2006; Lohar et al. 2004).
Activation of the root-nodule organogenic program in distinct foci after cytokinin diffusion as well as in the gain-offunction $s n f 2$ mutants appears to position one or more regulatory mechanisms limiting the response of cortical cells downstream of both the cytokinin signal and its LHK1-mediated perception. Corroborating this notion, we discovered that ecotypes and related cross-fertile species of Lotus, L. japonicus Gifu, L. japonicus MG-20, L. filicaulis, and L. burttii show differences in the transport, perception, or response to exogenously applied cytokinin. Only the L. japonicus ecotype Gifu responds by forming nodule primordia on the roots. No differences, however, were found in the coding region of $L h k l$ when comparing the sequences between Gifu and MG-20. Differences in the sensitivity or level of the LHK1 receptor could also contribute to the observed variation upon cytokinin treatment, and if so, this variation should then be revoked following transformation with the $s n f 2$ gene originating from L. japonicus Gifu. One possibility is that, in the ecotype Gifu, MG-20, and L. burttii, the level of the LHK1 control the cytokinin response. However, as identified by quantitative trait locus mapping, several genes are involved in the formation of the cytokinin-induced nodule. Further investigations are, therefore, needed to establish what the exact differences are between these ecotypes giving this very clear variation in phenotype. Irrespective of this, the ability of cytokinin to induce primordia in the $L$. $j a$ poncius Gifu ecotype provides an easy screen for assigning the position of new uncharacterized mutations upstream or downstream of the $L h k l$ receptor function in this ecotype.

\section{MATERIALS AND METHODS}

\section{Plant growth conditions.}

Lotus japonicus ecotype Gifu B-129 was used as a wild-type control. Seeds were surface-sterilized as previously described (Handberg and Stougaard 1992) and were grown on wet filter paper for 3 to 4 days. Plants were then grown in petri dishes with solid quarter-strength B\&D medium slants with or without $10^{-8}$ M BAP (Broughton and Dilworth 1971). The plants were left for at least 4 weeks before analysis for the presence of nodules. For growth on quarter-strength B\&D with and without BAP, filter paper was placed between the agar and the roots to prevent the roots growing into the agar. The plants were grown in a vertical position in growth boxes, keeping the roots in the dark. Growth chamber conditions were 18-h day and 6-h night cycles at $21^{\circ} \mathrm{C}$. For nodulation investigations, each petri dish was inoculated with $400 \mu \mathrm{l}$ of a 1:100- $\mu$ l dilution of Mesorhizobium loti R7A culture or MAFF303099 (optical density at $600 \mathrm{~nm}$ of approximately 0.01 ). Nodule numbers were scored on at least 20 plants.

For the measurements of primary and lateral roots, the number of plants tested was 40 for $l h k l-1$ with and without BAP, whereas $n=50$ for $\operatorname{snf} 2$ and WT with and without BAP.

For Nin::GUS investigations, 5-day-old seedlings were transferred to quarter-strength B\&D plates. After 2 days of growth, the plants were treated either with $10^{-7} \mathrm{M}$ Nod factor or $10^{-6}$, $10^{-7}, 10^{-8}$, and $10^{-9} \mathrm{M}$ BAP for $48 \mathrm{~h}$ in the dark $(n=40$ for each treatment). The plants were stained using a GUS reaction buffer $\left(0.05 \%\right.$ X-gluc, $50 \mathrm{mM} \mathrm{NaPO}_{4}$ (pH 7.0), $10 \mathrm{mM}$ EDTA, $20 \%$ methanol) for $24 \mathrm{~h}$ at $37^{\circ} \mathrm{C}$.

Mutant plants and numbers tested for cytokinin response $\left(10^{-8}\right.$ M BAP) were $n f r l-1$ (18), nfr5-2 (20), symRK-3 (23), nup133-1 (27), nup85-1 (17), castor-1 (37), pollux-2 (18), ccamk-2 (37), cyclops-2 (16), nin-2 (10), nin-3 (10), nspl-1 (59), nsp2-3 (27), pirl-1 (35), lhkl-1 (19), sym10 (37), symll (39), sym43 (37), harl-3 (32), astray (36), and wild type (267). The symbiotic phenotypes of these mutants were previously described (Heckmann et al. 2006; Imaizumi-Anraku et 
al. 2005; Kanamori et al. 2006; Krusell et al. 2002; Madsen et al. 2003; Murakami et al. 2007; Murray et al. 2007; Nishimura et al. 2002a and b; Radutoiu et al. 2003; Saito et al. 2007; Sandal et al. 2006; Schauser et al. 1999; Stracke et al. 2002; Suganuma et al. 2003; Tirichine et al. 2006a; Yano et al. 2008; Yokota et al. 2009). Differences in the tested biological parameters (e.g., number of nodules) between mutant (astray and harl) and wild-type plants were analyzed in Excel using the Student's $t$-test (assuming equal variance when appropriate). For all tests, a significant level of 5\% was applied.

\section{Histological sections.}

The nodule sections were analyzed by light microscopy. The nodules were stored in $70 \%$ ethanol and were then fixed in a glutaraldehyde (1\%)-paraformaldehyde (4\%) mix buffered to $\mathrm{pH}$ 7.8. The nodules were embedded in Technovit 7100 (Heraeus Kulzer GmbH, Wehrheim, Germany), and 5- $\mu$ m sections were stained with $0.1 \%$ toluidine blue or ruthenium red.

\section{Expression analysis.}

Approximately 25 plants were grown for 2 weeks in sealed plant containers with clay granula and quarter-strength $\mathrm{B} \& \mathrm{D}$ with $0.1 \mathrm{mM} \mathrm{KNO}_{3}$. The plants were grown on an iron mesh for easy transfer of plants into liquid without harming the roots. The plants were transferred to new containers holding $100 \mathrm{ml}$ of media, either with $10^{-7} \mathrm{M}$ Nod factor or $10^{-8} \mathrm{M}$ BAP for 3,6 , and $12 \mathrm{~h}$. Three biological replicates were performed for each treatment.

Total RNA from $M$. loti-inoculated, Nod factor-, or BAPtreated roots was extracted using a combination of a modified "hot borate" method (Wan and Wilkins 1994) and TRIZOL (Sigma-Aldrich, Danmark A/S, Brøndby, Denmark). The RNA was DNase-treated using RQ1-DNAse (Promega Biotech AB, Nacka, Sweden), and cDNA synthesis was performed using the reverse transcriptase RevertAid M-MuLV reverse transcriptase (Fermentas GmbH, St. Leon-Rot, Germany). Real-time polymerase chain reaction (PCR) was performed with the LightCycler 480 (Roche Diagnostics A/S, Hvidovre, Denmark) using LightCycler 480 SYBR Green I master (Roche).

The transcript levels of the four genes and three reference genes were determined by quantitative real-time PCR as previously described (Radutoiu et al. 2003). The ATP (ATP synthase), UBC (ubiquitin-conjugating enzyme), PP2A (protein phosphatase 2A), Lhk1, Lrr5, and Nin primers used for realtime PCR were as previously described (Tirichine et al. 2007). The Sstl primers were as described by Bek and associates (2010). Normalized relative ratios of each nodulin gene and three independent reference genes (ATP, PP2A, and UBC) were calculated using Relative Quantification Software (Roche). Three technical replicates for each biological replicate were included in the Lightcycler runs. The geometric mean of relative expression ratios for three biological and three technical repetitions were calculated and the corresponding upper and lower $95 \%$ confidence intervals were calculated (Vandesompele et al. 2002).

\section{Hormone treatment and transformation.}

To assess the effect of nitrate, ethylene, and ABA on the formation of cytokinin-induced nodules, L. japonicus Gifu wildtype plants were grown on solid quarter-strength $\mathrm{B} \& \mathrm{D}$ slants for 42 days with increasing concentrations of $\mathrm{KNO}_{3}, \mathrm{ACC}$, AVG, and ABA (cis,trans-ABA) with or without addition of BAP. The number of nodules developed on plants after rhizobial infection or BAP treatment were recorded. At least 30 plants were used for each experiment performed on plates. Transgenic hairy roots and nodulation tests were done as previously described (Stougaard 1995).

\section{ACKNOWLEDGMENTS}

A. B. Heckmann has a postdoctoral fellowship from the Danish National Science Research Council (FNU), and this work was supported by the Danish National Research Foundation. We are grateful to F. Pedersen for plant care.

\section{LITERATURE CITED}

Allen, E. K., Allen, O. N., and Newman, A. S. 1953. Pseudonodulation of leguminous plants induced by 2-bromo-3,5-dichlorobenzoic acid. Am. J. Bot. 40:429-435.

Bauer, P., Ratet, P., Crespi, M. D., Schultze, M., and Kondorosi, A. 1996. Nod factors and cytokinins induce similar cortical cell division, amyloplast deposition and MsEnod $12 \mathrm{~A}$ expression patterns in alfalfa roots. Plant J. 10:91-105.

Bek, A. S., Sauer, J., Thygesen, M. B., Duus, J. O., Petersen, B. O., Thirup, S., James, E., Jensen, K. J., Stougaard, J., and Radutoiu, S. 2010. Improved characterization of nod factors and genetically based variation in LysM receptor domains identify amino acids expendable for nod factor recognition in Lotus spp. Mol. Plant-Microbe Interact. 23:58-66

Broughton, W. J., and Dilworth, M. J. 1971. Control of leghaemoglobin synthesis in snake Beans. Biochem. J. 125:1075-1080.

Caetano-Anollés, G., and Gresshoff, P. M. 1991. Plant genetic control of nodulation. Annu. Rev. Microbiol. 45:345-382.

Combier, J. P., Frugier, F., de Billy, F., Boualem, A., El-Yahyaoui, F., Moreau, S., Vernie, T., Ott, T., Gamas, P., Crespi, M., and Niebel, A. 2006. MtHAP2-1 is a key transcriptional regulator of symbiotic nodule development regulated by microRNA169 in Medicago truncatula. Genes Dev. 20:3084-3088.

Cooper, J. B., and Long, S. R. 1994. Morphogenetic rescue of Rhizobium meliloti nodulation mutants by trans-zeatin secretion. Plant Cell 6:215225.

Debi, B. R., Taketa, S., and Ichii, M. 2005. Cytokinin inhibits lateral root initiation but stimulates lateral root elongation in rice (Oryza sativa). Plant Physiol. 162:507-515.

Ding, Y., Kalo, P., Yendrek, C., Sun, J., Liang, Y., Marsh, J. F., Harris, J. M., and Oldroyd, G. E. D. 2008. Abscisic acid coordinates nod factor and cytokinin signaling during the regulation of nodulation in Medicago truncatula. Plant Cell 20:2681-2695.

Fang, Y. W., and Hirsch, A. M. 1998. Studying early nodulin gene ENOD40 expression and induction by nodulation factor and cytokinin in transgenic alfalfa. Plant Physiol. 116:53-68.

Frugier, F., Kosuta, S., Murray, J., Crespi, M., and Szczyglowski, K. 2008. Cytokinin: Secret agent of symbiosis. Trends Plant Sci. 13:115-120.

Gonzalez-Rizzo, S., Crespi, M., and Frugier, F. 2006. The Medicago truncatula CRE1 cytokinin receptor regulates lateral root development and early symbiotic interaction with Sinorhizobium meliloti. Plant Cell 18:2680-2693.

Goodlass, G., and Smith, K. A. 1979. Effects of ethylene on root extension and nodulation of pea (Pisum sativum L.) and white clover (Trifolium repens L.). Plant Soil 51:387-395.

Groth, M., Takeda, N., Perry, J., Uchida, H., Dräxl, S., Brachmann, A., Sato, S., Tabata, S., Kawaguchi, M., Wang, T. L., and Parniske, M. 2010. NENA, a Lotus japonicus homolog of Sec13, is required for rhizodermal infection by arbuscular mycorrhiza fungi and rhizobia but dispensable for cortical endosymbiotic development. Plant Cell 22:2509-2526.

Handberg, K., and Stougaard, J. 1992. Lotus japonicus, an autogamous, diploid legume species for classical and molecular-genetics. Plant J. 2:487-496.

Heckmann, A. B., Lombardo, F., Miwa, H., Perry, J. A., Bunnewell, S., Parniske, M., Wang, T. L., and Downie, J. A. 2006. Lotus japonicus nodulation requires two GRAS domain regulators, one of which is functionally conserved in a non-legume. Plant Physiol. 142:1739-1750.

Heidstra, R., Yang, W. C., Yalcin, Y., Peck, S., Emons, A. M., van Kammen, A., and Bisseling, T. 1997. Ethylene provides positional information on cortical cell division but is not involved in Nod factorinduced root hair tip growth in Rhizobium-legume interaction. Development 124:1781-1787.

Held, M., Hossain, M. S., Yokota, K., Bonfante, P., Stougaard, J., and Szczyglowski, K. 2010. Common and not so common symbiotic entry. Trends Plant Sci. 15:540-545.

Hirsch, A. M., and Fang, Y. W. 1994. Plant hormones and nodulationWhat's the connection? Plant Mol. Biol. 26:5-9.

Hirsch, A. M., Bhuvaneswari, T. V., Torrey, J. G., and Bisseling, T. 1989. Early nodulin genes are induced in Alfalfa root outgrowths elicited by auxin transport inhibitors. Proc. Natl. Acad. Sci. U.S.A. 86:1244-1248. 
Hirsch, A. M., Fang, Y., Asad, S., and Kapulnik, Y. 1997. The role of phytohormones in plant-microbe symbioses. Plant Soil 194:171-184.

Hirsch, S., Kim, J., Munoz, A., Heckmann, A. B., Downie, J. A., and Oldroyd, G. E. D. 2009. GRAS proteins form a DNA binding complex to induce gene expression during nodulation signaling in Medicago truncatula. Plant Cell 21:545-557.

Høgslund, N., Radutoiu, S., Krusell, L., Voroshilova, V., Hannah, M. A., Goffard, N., Sanchez, D. H., Lippold, F., Ott, T., Sato, S., Tabata, S., Liboriussen, P., Lohmann, G. V., Schauser, L., Weiller, G. F., Udvardi, M. K., and Stougaard, J. 2009. Dissection of symbiosis and organ development by integrated transcriptome analysis of Lotus japonicus mutant and wild-type plants. Plos One 4. Published online.

Imaizumi-Anraku, H., Takeda, N., Charpentier, M., Perry, J., Miwa, H., Umehara, Y., Kouchi, H., Murakami, Y., Mulder, L., Vickers, K., Pike, J., Downie, J. A., Wang, T., Sato, S., Asamizu, E., Tabata, S. Yoshikawa, M., Murooka, Y., Wu, G. J., Kawaguchi, M., Kawasaki, S., Parniske, M., and Hayashi, M. 2005. Plastid proteins crucial for symbiotic fungal and bacterial entry into plant roots. Nature 433:527531

Kanamori, N., Madsen, L. H., Radutoiu, S., Frantescu, M., Quistgaard, E. M. H., Miwa, H., Downie, J. A., James, E. K., Felle, H. H., Haaning, L. L., Jensen, T. H., Sato, S., Nakamura, Y., Tabata, S., Sandal, N., and Stougaard, J. 2006. A nucleoporin is required for induction of $\mathrm{Ca}^{2+}$ spiking in legume nodule development and essential for rhizobial and fungal symbiosis. Proc. Natl. Acad. Sci. U.S.A. 103:359-364.

Krusell, L., Madsen, L. H., Sato, S., Aubert, G., Genua, A., Szczyglowski, K., Duc, G., Kaneko, T., Tabata, S., de Bruijn, F., Pajuelo, E., Sandal, N., and Stougaard, J. 2002. Shoot control of root development and nodulation is mediated by a receptor-like kinase. Nature 420:422-426.

Krusell, L., Krause, K., Ott, T., Desbrosses, G., Kramer, U., Sato, S., Nakamura, Y., Tabata, S., James, E. K., Sandal, N., Stougaard, J., Kawaguchi, M., Miyamoto, A., Suganuma, N., and Udvardi, M. K. 2005. The sulfate transporter SST1 is crucial for symbiotic nitrogen fixation in Lotus japonicus root nodules. Plant Cell 17:1625-1636.

Laplaze, L., Benkova, E., Casimiro, I., Maes, L., Vanneste, S., Swarup, R. Weijers, D., Calvo, V., Parizot, B., Herrera-Rodriguez, M. B., Offringa, R., Graham, N., Doumas, P., Friml, J., Bogusz, D., Beeckman, T., and Bennett, M. 2007. Cytokinins act directly on lateral root founder cells to inhibit root initiation. Plant Cell 19:3889-3900.

Lohar, D. P., Schaff, J. E., Laskey, J. G., Kieber, J. J. , Bilyeu, K. D., and Bird, D. M. 2004. Cytokinins play opposite roles in lateral root formation, and nematode and Rhizobial symbioses. Plant J. 38:203-214.

Madsen, E. B., Madsen, L. H., Radutoiu, S., Olbryt, M., Rakwalska, M., Szczyglowski, K., Sato, S., Kaneko, T., Tabata, S., Sandal, N., and Stougaard, J. 2003. A receptor kinase gene of the LysM type is involved in legume perception of rhizobial signals. Nature 425:637-640.

Madsen, L. H., Tirichine, L., Jurkiewicz, A., Sullivan, J. T., Heckmann, A. B., Bek, A. S., Ronson, C. W., James, E. K., and Stougaard, J. 2010. The molecular network governing nodule organogenesis and infection in the model legume Lotus japonicus. Nat. Commun. 1:10. doi: 10.1038/ncomms 1009. Published online.

Maekawa, T., Maekawa-Yoshikawa, M., Takeda, N., Imaizumi-Anraku, H., Murooka, Y., and Hayashi, M. 2009. Gibberellin controls the nodulation signaling pathway in Lotus japonicus. Plant J. 58:183-194.

Mathesius, U., Charon, C., Rolfe, B. G., Kondorosi, A., and Crespi, M. 2000. Temporal and spatial order of events during the induction of cortical cell divisions in white clover by Rhizobium leguminosarum bv. trifolii inoculation or localized cytokinin addition. Mol. Plant-Microbe Interact. 13:617-628.

Mathews, A., Carroll, B. J., and Gresshoff, P. M. 1989. Development of Bradyrhizobium infections in a supernodulating and non-nodulating mutant of soybean (Glycine max (L.) Merr). Protoplasma 150:40-47.

Miwa H., Sun J., Oldroyd G. E. D., and Downie J. A. 2006. Analysis of calcium spiking using a cameleon calcium sensor reveals that nodulation gene expression is regulated by calcium spike number and the developmental status of the cell. Plant J. 48:883-894.

Murakami, Y., Miwa, H., Imaizumi-Anraku, H., Kouchi, H., Downie, J. A. Kawaguchi, M., and Kawasaki, S. 2007. Positional cloning identifies Lotus japonicus NSP2, a putative transcription factor of the GRAS family, required for NIN and ENOD4O gene expression in nodule initiation. DNA Res. 13:255-265.

Murray, J. D., Karas, B. J., Sato, S., Tabata, S., Amyot, L., and Szczyglowski, K. 2007. A cytokinin perception mutant colonized by Rhizobium in the abscene of nodule organogenesis. Science 315:101-104.

Nishimura, R., Ohmori, M., Fujita, H., and Kawaguchi, M. 2002a. A Lotus basic leucine zipper protein with a RING-finger motif negatively regulates the developmental program of nodulation. Proc. Natl. Acad. Sci. U.S.A. 99:15206-15210.

Nishimura, R., Ohmori, M., and Kawaguchi, M. 2002b. The novel symbiotic phenotype of enhanced-nodulating mutant of Lotus japonicus: astray mutant is an early nodulating mutant with wider nodulation zone. Plant Cell Physiol. 43:853-859.

Nukui, N., Ezura, H., Yuhashi, K., Yasuta, T., and Minamisawa, K. 2000. Effects of ethylene precursor and inhibitors for ethylene biosynthesis and perception on nodulation in Lotus japonicus and Macroptilium atropurpureum. Plant Cell Physiol. 41:893-897.

Oka-Kira, E., and Kawaguchi, M. 2006. Long-distance signaling to control root nodule number. Curr. Opin. Plant Biol. 9:496-502.

Okamoto, S., Ohnishi, E., Sato, S., Takahashi, H., Nakazono, M., Tabata, S., and Kawaguchi, M. 2009. Nod factor/nitrate-induced CLE genes that drive HAR 1-mediated systemic regulation of nodulation. Plant Cell Physiol. 50:67-77.

Oldroyd, G. E. D. 2007. Nodules and hormones. Science 315:52-53.

Oldroyd, G., and Downie, J. 2008. Coordinating nodule morphogenesis with rhizobial infection in legumes. Annu. Rev. Plant Biol. 59:519-546.

Oldroyd, G. E. D., Mitra, R. M., Wais, R. J., and Long, S. R. 2001. Evidence for structurally specific negative feedback in the Nod factor signal transduction pathway. Plant J. 28:191-199.

Plet, J., Wasson, A., Ariel, F., Le Signor, C., Baker, D., Mathesius, U., Crespi, M., and Frugier, F. 2011. MtCRE1-dependent cytokinin signaling integrates bacterial and plant cues to coordinate symbiotic nodule organogenesis in Medicago truncatula. Plant J. 65:622-633.

Peters, N. K., and Cristestes, D. K. 1989. Nodule formation is stimulated by the ethylene inhibitor aminoethoxyvinylglycine. Plant Physiol. 91:690-693.

Radutoiu, S., Madsen, L. H., Madsen, E. B., Felle, H. H., Umehara, Y., Gronlund, M., Sato, S., Nakamura, Y., Tabata, S., Sandal, N., and Stougaard, J. 2003. Plant recognition of symbiotic bacteria requires two LysM receptor-like kinases. Nature 425:585-592.

Radutoiu, S., Madsen, L. H., Madsen, E. B., Jurkiewicz, A., Fukai, E., Quistgaard, E. M. H., Albrektsen, A. S., James, E. K., Thirup, S., and Stougaard, J. 2007. LysM domains mediate lipochitin-oligosaccharide recognition and $N f r$ genes extend the symbiotic range. EMBO (Eur. Mol. Biol. Organ.) J. 26:3923-3935.

Sagan, M., and Gresshoff, P. M. 1996. Developmental mapping of nodulation events in Pea (Pisum sativum L.) using supernodulating plant genotypes and bacyterial variability reveals both plant and Rhizobium control of nodulation regulation. Plant Science 117:167-179.

Saito, K., Yoshikawa, M., Yano, K., Miwa, H., Uchida, H., Asamizu, E., Sato, S., Tabata, S., Imaizumi-Anraku, H., Umehara, Y., Kouchi, H., Murooka, Y., Szczyglowski, K., Downie, J.A., Parniske, M., Hayashi, M., and Kawaguchi, M. 2007. NUCLEOPORIN85 is required for calcium spiking, fungal and bacterial symbioses, and seed production in Lotus japonicus. Plant Cell 19:610-624.

Sandal, N., Petersen, T. R., Murray, J., Umehara, Y., Karas, B., Yano, K., Kumagai, H., Yoshikawa, M., Saito, K., Hayashi, M., Murakami, Y., Wang, X. W., Hakoyama, T., Imaizumi-Anraku, H., Sato, S., Kato, T., Chen, W. L., Hossain, M. S., Shibata, S., Wang, T. L., Yokota, K., Larsen, K., Kanamori, N., Madsen, E., Radutoiu, S., Madsen, L. H., Radu, T. G., Krusell, L., Ooki, Y., Banba, M., Betti, M., Rispail, N., Skot, L., Tuck, E., Perry, J., Yoshida, S., Vickers, K., Pike, J., Mulder, L., Charpentier, M., Muller, J., Ohtomo, R., Kojima, T., Ando, S., Marquez, A. J., Gresshoff, P. M., Harada, K., Webb, J., Hata, S., Suganuma, N., Kouchi, H., Kawasaki, S., Tabata, S., Parniske, M., Szczyglowski, K., Kawaguchi, M., and Stougaard, J. 2006. Genetics of symbiosis in Lotus japonicus: Recombinant inbred lines, comparative genetic maps, and map position of 35 symbiotic loci. Mol. PlantMicrobe Interact. 19:80-91

Schauser, L., Roussis, A., Stiller, J., and Stougaard, J. 1999. A plant regulator controlling development of symbiotic root nodules. Nature 402:191195.

Soeno, K., Goda, H., Ishii, T., Ogura, T., Tachikawa, T., Sasaki, E., Yoshida, S., Fujioka, S., Asami, T., and Shimida, Y. 2010. Auxin biosynthesis inhibitors, identified by a genomics-based approach, provide insights into auxin biosynthesis. Plant Cell Physiol. 51:524-536.

Stougaard, J. 1995. Agrobacterium rhizogenes as a vector for transforming higher plants. Methods Mol. Biol. 49:46-61.

Stracke, S., Kistner, C., Yoshida, S., Mulder, L., Sato, S., Kaneko, T., Tabata, S., Sandal, N., Stougaard, J., Szczyglowski, K., and Parniske, M. 2002. A plant receptor-like kinase required for both bacterial and fungal symbiosis. Nature 417:959-962.

Suganuma, N., Nakamura, Y., Yamamoto, M., Ohta, T., Koiwa, H., Akao, S., and Kawaguchi, M. 2003. The Lotus japonicus Sen1 gene controls rhizobial differentiation into nitrogen-fixing bacteroids in nodules. Mol. Genet Genomics 269:312-320.

Suzuki, A., Akune, M., Kogiso, M., Imagama, Y., Osuki, K., Uchiumi, T., Higashi, S., Han, S. Y., Yoshida, S., Asami, T., and Abe, M. 2004. Control of nodule number by the phytohormone abscisic acid in the roots of two leguminous species. Plant Cell Physiol. 45:914-922.

Szczyglowski, K., Shaw, R. S., Wopereis, J., Copeland, S., Hamburger, D., 
Kaslborski, B., Dazzo, F. B., and de Bruijn, F. J. 1998. Nodule organogenesis and symbiotic mutants of the model legume Lotus japonicus. Mol. Plant-Microbe Interact. 11:684-697.

Takei, K., Sakakibara, H., Taniguchi, M., and Sugiyama, T. 2001. Nitrogen-dependent accumulation of cytokinins in root and translocation to leaf: Implication of cytokinin species that induces gene expression of maize response regulator. Plant Cell Physiol. 42:85-93.

Tirichine, L., Imaizumi-Anraku, H., Yoshida, S., Murakami, Y., Madsen, L. H., Miwa, H., Nakagawa, T., Sandal, N., Albrektsen, A. S., Kawaguchi, M., Downie, A., Sato, S., Tabata, S., Kouchi, H., Parniske, M., Kawasaki, S., and Stougaard, J. 2006a. Deregulation of a $\mathrm{Ca}^{2+} /$ calmodulin-dependent kinase leads to spontaneous nodule development. Nature 441:1153-1156.

Tirichine, L., James, E. K., Sandal, N., and Stougaard, J. 2006b. Spontaneous root-nodule formation in the model legume Lotus japonicus: A novel class of mutants nodulates in the absence of rhizobia. Mol. Plant-Microbe Interact. 19:373-382.

Tirichine, L., Sandal, N., Madsen, L. H., Radutoiu, S., Albrektsen, A. S., Sato, S., Asamizu, E., Tabata, S., and Stougaard, J. 2007. A gain-offunction mutation in a cytokinin receptor triggers spontaneous root nodule organogenesis. Science 315, 104-107.

Tominaga, A., Nagata, M., Futsuki, K., Abe, H., Uchiumi, T., Abe, M., Kucho, K., Hashiguchi, M., Akashi, R., Hirsch, A. M., Arima, S., and Suzuki, A. 2009. Enhanced nodulation and nitrogen fixation in the ABA low-sensitive mutant enfl (enhanced nitrogen fixation 1) of Lotus japonicus. Plant Physiol. 151:1965-1976.

Vandesompele, J., De Preter, K., Pattyn, F., Poppe, B., Van Roy, N., De Paepe, A., and Speleman, F. 2002. Accurate normalization of real-time quantitative RT-PCR data by geometric averaging of multiple internal control genes. Genome Biol. 3:research0034.0031-0034.0011. Published online. van Spronsen, P. C., Grønlund, M., Bras, C. P., Spaink, H. P., and Kijne, J. W. 2001. Cell biological changes of outer cortical root cells in early determinate nodulation. Mol. Plant-Microbe Interact. 14:839-847.

Wan, C. Y., and Wilkins, T. A. 1994. A modified hot borate method significantly enhances the yield of high-quality RNA from cotton (Gossypium hirsutum L.). Anal. Biochem. 223:7-12.

Werner, T., Motyka, V., Strnad, M., and Schmülling, T. 2001. Regulation of plant growth by cytokinin. Proc. Natl. Acad. Sci. U.S.A. 98:1048710492.

Wopereis, J., Pajuelo, E., Dazzo, F. B., Jiang, Q. Y., Gresshoff, P. M., de Bruijn, F. J., Stougaard, J., and Szczyglowski, K. 2000. Short root mutant of Lotus japonicus with a dramatically altered symbiotic phenotype. Plant J. 23:97-114.

Yano, K., Yoshida, S., Muller, J., Singh, S., Banba, M., Vickers, K., Markmann, K., White, C., Schuller, B., Sato, S., Asamizu, E., Tabata, S., Murooka, Y., Perry, J., Wang, T. L., Kawaguchi, M., ImaizumiAnraku, H., Hayashi, M., and Parniske, M. 2008. CYCLOPS, a mediator of symbiotic intracellular accommodation. Proc. Natl. Acad. Sci. U.S.A. 105:20540-20545.

Yokota, K., Fukai, E., Madsen, L. H., Jurkiewicz, A., Rueda, P., Radutoiu, S., Held, M., Hossain, M. S., Szczyglowski, K., Morieri, G., Oldroyd, G. E. D., Downie, J. A., Nielsen, M. W., Rusek, A. M., Sato, S., Tabata, S., James, E. K., Oyaizu, H., Sandal, N., and Stougaard, J. 2009. Rearrangement of actin cytoskeleton mediates invasion of Lotus japonicus roots by Mesorhizobium loti. Plant Cell 21:267-284.

Zaat, S. A. J., Vanbrussel, A. A. N., Tak, T., Lugtenberg, B. J. J., and Kijne, J. W. 1989. The ethylene-inhibitor aminoethoxyvinylglycine restores normal nodulation by Rhizobium Leguminosarum biovar viciae on Vicia sativa subsp. nigra by suppressing the thick and short roots phenotype. Planta 177:141-150. 